\title{
TIGA SYARAT PENEBUSAN BOAS BAGI RUT DAN RELEVANSINYA DENGAN PENEBUSAN YESUS KRISTUS BAGI ORANG PERCAYA DITENGAH MASYARAKAT TRADISIONAL (ARKHAIK)
}

\author{
Efrim Wildatri \\ Institut Agama Kristen Negeri Toraja \\ Efrimwildtri46@gmail.com
}

Abstract:This paper wants to provide an explanation of the redemption that Boaz made for Ruth and its relationship with Christ's redemption for believers. Like Boaz, Christ is the only person who has the right, power and love to free and redeem His people from sin. Through the understanding that the author builds in this paper, it should help to further understand that the gift of salvation can only be obtained by faith and not by action, especially when we seek salvation based on myths and symbols of mortal worldly objects.

Keywords: redemption, grace, faith

Abstrak:Tulisan ini ingin memberi penjelasan tentang penebusan yang dilakukan Boas bagi Rut dan hubungannya dengan penebusan Kristus bagi orang percaya. Sebagaimana Boas, Kristus adalah satu-satunya pribadi yang berhak, berkuasa dan yang dengan kasih menginginkan untuk membebaskan dan menebus umat-Nya dari dosa. Melalui pemahaman yang penulis bangun dalam tulisan ini, hendaknya dapat menolong untuk semakin memahami bahwa anugerah keselamatan hanya dapat diperoleh dengan iman dan bukan karena tindakan, apalagi ketika kita mencari keselamatan itu berdasarkan mitos dan simbol dari benda-benda duniawi yang fana.

\section{Kata kunci: penebusan, anugerah, iman}

\section{PENDAHULUAN}

Penebusan adalah suatu konsep yang sangat penting dalam kekristenan, dimana iman Kristen meyakini bahwa keselamatan diperoleh oleh karena Anugerah dari Yesus Kristus yang telah menebus manusia dari hukuman dosa dan hanya dapat diperoleh dengan iman kepada-Nya. Secara etimologi, penebusan dalam perjanjian lama, dari bahasa ibrani yaitu: ג perjanjian baru dari bahasa Yunani: $\dot{\alpha} \boldsymbol{\pi} \mathbf{\lambda} \boldsymbol{\lambda} \boldsymbol{v} \boldsymbol{\rho} \boldsymbol{\omega} \boldsymbol{\sigma} \boldsymbol{\iota} \varsigma$, yang keduanya berarti tindakan membeli, merebut, melepaskan dan membebaskan. Dalam konteks perjanjian lama, penebusan berbicara mengenai pembebasan seseorang dari keterikatan sebagai budak. Selain itu Goel juga berbicara mengenai pembelian kembali hak milik keluarga yang telah dijual, serta kewajiban seorang 
kerabat laki-laki untuk mengawini seorang janda dari kerabatnya yang telah meninggal dan tidak meninggalkan keturunan untuk mendapatkan keturunan atas nama orang yang telah meninggal tersebut. Sedangkan dalam konteks perjanjian baru, penebusan berfokus pada karya Yesus dalam penyelamatan dan pembebasan umat yang percaya dari keterikatan dan penghambaan dosa. Inilah yang perlu di imani oleh orang kristen. Namun faktanya, pada saat sekarang, masih banyak orang kristen modern yang hidup dalam kepercayaan yang primitive, yang lebih memfokuskan diri pada kepercayaan akan mitos-mitos dan symbol, sehingga perlu untuk mendapatkan pemahaman tentang penebusan dari Yesus Kristus, lalu menghidupinya dalam keseharian sebagai umat yang telah ditebus.

\section{TUJUAN/MANFAAT}

Tulisan ini bertujuan untuk mempelajari kembali tema umum dari kitab Rut mengenai kisah penebusan yang dilakukan Boas bagi Rut dengan melihat tiga syarat penebusan yang dipenuhi oleh Boas yang sekaligus menunjukkan suatu gambaran yang indah tentang penebusan yang dilakukan oleh Yesus Kristus sebagai satu-satunya pribadi yang berhak, berkuasa dan berkeinginan untuk menebus manussia. Dan penebusan itu berlaku bagi setiap orang yang percaya dan mau menerima Kristus dengan iman sebagai satu-satunya juruselamat.

\section{PEMBAHASAN}

Dalam kitab Rut,Boas adalah tokoh yang muncul setelah penjelasan kemalangankemalangan yang menimpa Naomi dan keluarganya saat mereka berada di Moab. Setelah Naomi ditimpa kemalangan itu, ia kembali ke Betlehem bersama dengan salah satu menantunya yang memilih untuk tetap setia kepada Naomi yaitu Rut, Yang dengan tegas mengatakan "kemana engkau pergi kesitu jugalah aku pergi. Allahmulah Allahku dan bangsamulah bangsaku” Dan Rut yang telah mengakui dengan hati bahwa ia akan menyembah Allah yang disembah oleh Naomi membuktikan kesungguhan dari kalimat yang diucapkannya yang dapat di lihat dari perkataannya kepada mertuanya (Rut 2:2) yang menunjukkan bahwa ia cukup mengerti tentang firman Tuhan ${ }^{1}$ mengenai hak orang-orang miskin untuk datang memungut bulir-bulir jelai yang ditinggalkan (secara sengaja) oleh para penuai diladang yang telah ditetapkan oleh Allah sendiri didalam hukum taurat (Im 19:9). Boas sendiri baru muncul di pasal yang kedua, dimana ia ditampilkan sebagai kerabat dari suami Naomi yang kaya raya. Secara kebetulan Rut yang pergi

\footnotetext{
${ }^{1}$ Rannu Sanderan and Yohanes Krismantyo Susanta, "Pemahaman Tentang Sayap Dalam Kitab Rut: Studi Kritik Naratif," KAMASEAN: Jurnal Teologi Kristen 2, no. 1 (June 22, 2021): 47-58, https://doi.org/10.34307/kamasean.v2i1.33.
} 
memungut jelai sampai ke ladang milik Boas, dan disana Boas menunjukkan kasihnya dan kemurahan hatinya kepada Rut yang telah menampakkan kesetiaannya kepada Naomi sekaligus sebagai bentuk ketaatannya kepada Allah. Ia mengatakan kepada Rut bahwa atas kesetiaan dan semua yang telah ia lakukan terhadap Naomi serta keputusannya untuk percaya kepada Allah, ia layak mendapatkan semua itu, bahkan Allah akan memberkatinya lebih lagi (Rut 2:12).

Setelah peristiwa itu, Naomi membuat rencana agar Rut bertemu dengan Boas di tempat pengirikan dan memintanya untuk menebusnya. Naomi meminta Rut untuk berbaring dibawah selimut dekat kaki Boas dan dengan demikian ia berharap Boas mau menikahi Rut. Rut melakukan semua yang diperintahkan mertuanya Dan pada malam itu juga, Boas berjanji untuk melakukan semua yang diminta oleh Rut termasuk untuk menikahinya meskipun hukum taurat tidak mengharuskannya untuk melakukan hal itu ${ }^{2}$

Ada tiga syarat yang harus dipenuhi Boas sehingga ia menjadi kandidat yang layak untuk menebus, yaitu: ia haruslah seorang yang berhak menebus, berkuasa untuk menebus, dan yang berkeinginan untuk menebus ${ }^{3}$. Boas Berhak menebus. Hal ini dibuktikan ketika penanggalan kasut dari pihak pertama yang berkewajiban menebus Rut yang menjadi tanda penolakannya sehingga kewajiban untuk menebus dialihkan kepada Boas. Boas Berkuasa untuk Menebus. Pada pasal yang keempat dalam kitab Rut dapat dilihat bahwa Boas adalah seorang yang berpengaruh, yang dapat dengan mudah memanggil para tua-tua kota untuk datang menyelesaikan perkara yang dialami oleh seseorang, khususnya dalam kasus Rut. Boas berkeinginan untuk menebus. Hal ini dapat dilihat pada saat Boas langsung menyetujui permintaan Rut pada saat Rut datang ke tempat pengirikan dan berbaring dibawah kaki Boas. Ia menyatakan keinginan dan ketulusannya untuk menebus Rut.

\section{PENEBUSAN YESUS KRISTUS}

Seperti Boas yang menunjukkan kepeduliannya walaupun Rut adalah orang Moab yang bagi kaum Yahudi kerap dilihat sebagai kafir dan hina (U1. 23:3-6) ${ }^{4}$, demikian juga Kristus yang mengasihi umat-Nya, sekalipun mereka adalah umat yang penuh dosa dan yang patut untuk mendapatkan hukuman. Sebagaimana Boas memenuhi tiga syarat utama untuk menebus, demikian juga Kristus. Yesus sepenuhnya memiliki hak, kuasa, serta keinginan untuk menebus

\footnotetext{
${ }^{2}$ Alkitab: edisi studi; [yaitu Perjanjian Lama dan Perjanjian Baru dalam]; [the Indonesian new translation study Bible] (Jakarta: Lembaga Alkitab Indonesia, 2012).

3 denis green, Pembimbing Pada Pengenalan Perjanjian Lama, 14 (Malang: Penerbit Gandum Mas, 2019).

${ }^{4}$ Sanderan and Susanta, "Pemahaman Tentang Sayap Dalam Kitab Rut."
} 
manusia. Dia yang mencipta dan menjadikan semuanya ada termasuk manusia, sehingga sudah menjadi hak mutlak bagi-Nya untuk menebus dan menyelamatkan mereka dari hukuman dan belenggu dosa, dengan memberi diri-Nya mati dikayu salib dan bangkit pada hari ketiga yang menjadi jaminan keselamatan manusia. Ia Berhak, berkuasa, dan berkeinginan untuk menebus dan menganugerahkan keselamatan, termasuk kepada siapa keselamatan itu Dia perkenankan (Yoh 17:12).

\section{PENEBUSAN KRISTUS DALAM MASYARAKAT TRADISIONAL (ARKHAIK)}

Berbeda dengan kepercayaan Kristen, masyarakat tradisional lebih mengutamakan symbol-simbol dan mitos untuk dapat merasakan sesuatu Yang sacral. mitos sebenarnya merupakan simbol-simbol dalam wujud narasi. Dalam hal ini, mitos bukan hanya dipahami sebatas suatu imajinasi belaka atau melulu pertanda, tetapi imajinasi yang dimuat ke dalam bentuk cerita yang mengisahkan dewa-dewa, leluhur, para kesatria atau dunia supernatural ${ }^{5}$.sehingga Apapun disekitar yang bagi mereka dapat mewakili sesuatu Yang sacral itulah yang mereka percayai. sehingga masyarakat tradisional berpegang tidak hanya pada satu objek , tapi pada berbagai objek yang mereka yakini sebagai simbol kehadiran ilahi. Namun setelah kehadiran Yesus yang dengan kasih mau menebus manusia sebagai satu-satunya pribadi yang berhak, berkuasa dan berkeinginan untuk menebus manusia dari hukum dosa dan menganugerahkan hidup kekal kepadanya, semua symbol dan hal-hal mistik hilang kuasanya. Dalam mengingat kembali (anamnesis) peristiwa kelahiran, penyaliban, dan kebangkitan kembali Yesus, sejatinya iman Kristen tidak melibatkan ritual-ritual ingin kembali, mereka tidak berusaha untuk kembali kepada keabadian. Mereka melakukan pengingatan terhadap peristiwaperistiwa historis yang telah final tersebut bahwa yang diminta dari mereka hanyalah keteguhan hati iman yang sebenarnya kepada Yesus ${ }^{6}$. Namun kita tidak dapat memungkiri Fakta bahwa iman lebih dominan diperoleh (dipelajari) justru melalui budaya; dan secara konkrit lebih banyak melalui keteladanan dan interelasi individual. Dengan kata lain, kepercayaan atau iman lebih

\footnotetext{
${ }^{5}$ Rannu Sanderan, "INTUISI: Pendalaman Gagasan Hans-George Gadamer Tentang Intuisi Sebagai Supralogika," Jurnal Ilmiah Religiosity Entity Humanity (JIREH) 2, no. 2 (December 23, 2020): 114-25, https://doi.org/10.37364/jireh.v2i2.39.

${ }^{6}$ Rannu Sanderan, "Budaya Arkhaik Dalam Aktualisasi Agama Modern,” preprint (Open Science Framework, November 26, 2021), https://doi.org/10.31219/osf.io/s897g.
} 
dipengaruhi melalui pembentukan kultur $^{7}$. sebagai contoh, dalam Elemen penyembahan kekristenan ada liturgy yang sering dilihat sebagai ritus yang berulang-ulang namun pada dasarnya pola repetisi dalam liturgi turut membentuk karakter umat Kristen ${ }^{8}$. Sehingga dalam iman kristen,Tidak ada lagi hal-hal mistis dan kepercayaan yang ambigu karena orang percaya adalah mereka yang berelasi secara spiritual dengan Allah, yang dengan iman memperoleh anugerah keselamatan dari Yesus Kristus sang pribadi yang Berhak, Berkuasa, dan berkeinginan untuk menebus ciptaan-Nya.

\section{KESIMPULAN}

Penebusan adalah konsep teologi yang sangat penting dalam kekristenan, dimana penebusan berbicara mengenai karya penyelamatan yang dilakukan oleh Yesus Kristus yang dianugerahkan kepada umat yang kepadanya Dia berkenan. Gambaran penebusan yang dilakukan Boas kemudian menjadi sebuah gambaran tentang betapa indahnya kasih Kristus yang mau menebus kita karena Dia berhak, berkuasa dan berkeinginan untu menebus umat-Nya dan membebaskannya dari hukuman dosa. Hal ini berlaku kepada semua orang yang mau menerimaNya dengan iman dan bukan mencari keselamatan pada benda-benda yang fana. Sekalipun fakta bahwa iman sering dipengaruhi oleh sesuatu yang bersifat "kultur" namun harus selalu di pahami bahwa kita adalah umat yang berelasi secara spiritual dengan Allah, sehingga hal-hal yang berbau kultur tidak boleh kita pandang sebagai sesuatu yang dipercayai tapi sebagai sesuatu/sarana yang dapat semakin membentuk dan menumbuhkan iman kita kepada Allah.

\section{SARAN}

Pada saat ini, masih banyak orang (termasuk orang Kristen) yang hidup dalam keterikatan akan kepercayaan kepada hal-hal mistis dan symbol-simbol. Dan sebagai orang yang telah belajar dan percaya akan karya penebusan Kristus kita harus mampu menjadi pemberita kabar baik, memperkenalkan Kristus dan karya penebusan-Nya serta anugerah keselamatan yang ditawarkan-Nya,sambil tetap mengawasi diri sendiri sehingga tidak jatuh kedalam "penyembahan berhala modern” dan tetap hidup dalam terang kasih Kristus,

\footnotetext{
${ }^{7}$ Rannu Sanderan, "EXEMPLARY, MENEMUKENALI KUNCI PENDIDIKAN IMAN BAGI ANAK DALAM KELUARGA DAN PEMBELAJARAN AGAMA DI SEKOLAH," preprint (Open Science Framework, November 19, 2021), https://doi.org/10.31219/osf.io/bmtrk.

${ }^{8}$ Rannu Sanderan, "Heuristika Dalam Pendidikan Karakter Manusia Toraja Tradisional," BIA': Jurnal Teologi Dan Pendidikan Kristen Kontekstual 3, no. 2 (December 19, 2020): 306-27, https://doi.org/10.34307/b.v3i2.213.
} 


\section{DAFTAR PUSTAKA}

Alkitab: edisi studi; [yaitu Perjanjian Lama dan Perjanjian Baru dalam]; [the Indonesian new translation study Bible] (Jakarta: Lembaga Alkitab Indonesia, 2012).

Green denis, Pembimbing Pada Pengenalan Perjanjian Lama, 14 (Malang: Penerbit Gandum Mas, 2019).

Sanderan, Rannu. "Budaya Arkhaik Dalam Aktualisasi Agama Modern." Preprint. Open Science Framework, November 26, 2021. https://doi.org/10.31219/osf.io/s897g. . "EXEMPLARY, MENEMUKENALI KUNCI PENDIDIKAN IMAN BAGI ANAK DALAM KELUARGA DAN PEMBELAJARAN AGAMA DI SEKOLAH." Preprint. Open Science Framework, November 19, 2021. https://doi.org/10.31219/osf.io/bmtrk. . "Heuristika Dalam Pendidikan Karakter Manusia Toraja Tradisional." BIA': Jurnal Teologi Dan Pendidikan Kristen Kontekstual 3, no. 2 (December 19, 2020): 306-27. https://doi.org/10.34307/b.v3i2.213. . "INTUISI: Pendalaman Gagasan Hans-George Gadamer Tentang Intuisi Sebagai Supralogika." Jurnal Ilmiah Religiosity Entity Humanity (JIREH) 2, no. 2 (December 23, 2020): 114-25. https://doi.org/10.37364/jireh.v2i2.39.

Sanderan, Rannu, and Yohanes Krismantyo Susanta. "Pemahaman Tentang Sayap Dalam Kitab Rut: Studi Kritik Naratif." KAMASEAN: Jurnal Teologi Kristen 2, no. 1 (June 22, 2021): 47-58. https://doi.org/10.34307/kamasean.v2i1.33. 